\title{
Hydrogen bonded complexes of cyanuric acid with pyridine and guanidinium carbonate
}

\author{
K SIVASHANKAR \\ Chemistry and Physics of Materials Unit, Jawaharlal Nehru Centre for \\ Advanced Scientific Research, Jakkur PO, Bangalore 560 064, India \\ e-mail: shivchem@jncasr.ac.in
}

MS received 31 August 2000

\begin{abstract}
Hydrogen bonded complexes of cyanuric acid (CA) with pyridine, $\left[\mathrm{C}_{3} \mathrm{~N}_{3} \mathrm{H}_{3} \mathrm{O}_{3}: \mathrm{C}_{5} \mathrm{H}_{5} \mathrm{~N}\right], \mathbf{1}$, and guanidinium carbonate $\left[\mathrm{C}_{3} \mathrm{H}_{2} \mathrm{~N}_{3}\right]\left[\mathrm{C}\left(\mathrm{NH}_{2}\right)_{3}\right], 2$, have been prepared at room temperature and characterized by single-crystal $\mathrm{X}$-ray diffraction. Structure of 1 shows pyridine molecules substituting the inter-tape hydrogen bond in $\mathrm{CA}$ by $\mathrm{N}-\mathrm{H} \ldots \mathrm{N}$ and $\mathrm{C}-\mathrm{H}$... O hydrogen bonds. The structure reveals CA-pyridine hydrogen-bonded single helices held together by dimeric $\mathrm{N}-\mathrm{H}$... O hydrogen bonding between CA molecules. In $\mathbf{2}$, the CA tapes, resembling a sine wave interact with the guanidinium cations through $\mathrm{N}-\mathrm{H} \ldots \mathrm{O}$ and $\mathrm{N}-\mathrm{H} \ldots \mathrm{N}$ hydrogen bonds forming guanidinium cyanurate sheets.
\end{abstract}

Keywords. Cyanuric acid-pyridine adduct; guanidinium cyanurate; single helices; crystal structure analysis.

\section{Introduction}

Cyanuric acid, CA, crystallizes as molecular tapes with dimeric $\mathrm{N}-\mathrm{H} . . . \mathrm{O}$ hydrogen bonding ${ }^{1}$. Adjacent tapes are held together by $\mathrm{N}-\mathrm{H}$...O interactions forming $\mathrm{CA}$ molecular sheets perpendicular to the $a$ axis as shown in figure 1. Cyanuric acid has been co-crystallized with several heterocyclic molecules such as bipyridyl ${ }^{2,3}$ to obtain interesting intermolecular hydrogen-bonded assemblies. With melamine, CA forms the well-known rosette structure giving rise to channels ${ }^{4}$. We have investigated the adducts of CA with pyridine and guanidinium carbonate and have obtained novel hydrogenbonded structures. In this work we describe the interesting features of these adducts.

\section{Experimental}

Rod-shaped single crystals of the 1:1 complex of CA with pyridine were obtained from a solution of $\mathrm{CA}$ in pyridine at room temperature. The composition of this complex was $\mathrm{C}_{3} \mathrm{~N}_{3} \mathrm{H}_{3} \mathrm{O}_{3}: \mathrm{C}_{5} \mathrm{H}_{5} \mathrm{~N}$, 1. Good quality single crystals of the adduct of $\mathrm{CA}$ with guanidinium carbonate (GC) were obtained from an aqueous solution containing 1 mmol each of $\mathrm{CA}$ and GC. The composition of the adduct is $\left[\mathrm{C}_{3} \mathrm{H}_{2} \mathrm{~N}_{3}\right]\left[\mathrm{C}\left(\mathrm{NH}_{2}\right)_{3}\right], \mathbf{2}$. Crystal data of $\mathbf{1}$ and $\mathbf{2}$ are listed in table 1.

High quality single crystals were chosen after careful examination under a polarizing microscope. X-ray diffraction intensities were measured at room temperature by $\omega$ scans using a Siemens three-circle diffractometer attached to a CCD area detector and a 


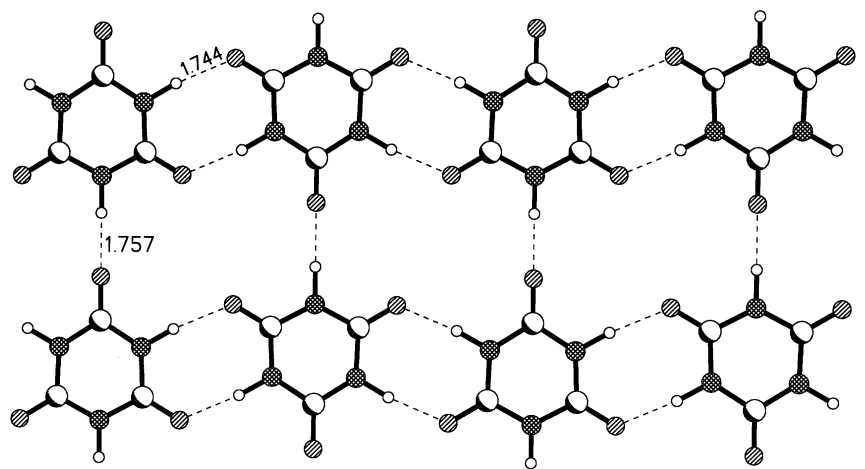

Figure 1. Structure of $\mathrm{CA}$ with tapes formed by $\mathrm{N}-\mathrm{H}$... O hydrogen bonds along the $c$ axis and the inter-tape $\mathrm{N}-\mathrm{H}$... O hydrogen bonds along the $b$ axis.

Table 1. Crystal data for 1 and 2

\begin{tabular}{|c|c|c|}
\hline & 1 & 2 \\
\hline Formula & $\mathrm{C}_{3} \mathrm{~N}_{3} \mathrm{H}_{3} \mathrm{O}_{3}: \mathrm{C}_{5} \mathrm{H}_{5} \mathrm{~N}$ & {$\left[\mathrm{C}_{3} \mathrm{H}_{2} \mathrm{~N}_{3} \mathrm{O}_{3}\right]\left[\mathrm{C}\left(\mathrm{NH}_{2}\right)_{3}\right]$} \\
\hline Molecular weight & $208 \cdot 18$ & $47 \cdot 04$ \\
\hline Crystal system & Monoclinic & Triclinic \\
\hline Space group & $P 2_{1} / c$ & $P-1$ \\
\hline$a(\AA)$ & $10 \cdot 8152(4)$ & $3 \cdot 7745(5)$ \\
\hline$b(\AA)$ & $11.9889(10)$ & $9 \cdot 8488(14)$ \\
\hline$c(\AA)$ & $7 \cdot 4529(2)$ & $10 \cdot 499(2)$ \\
\hline$\alpha$ & 90 & $87.924(3)$ \\
\hline$\beta$ & $94 \cdot 282(2)$ & $83 \cdot 217(2)$ \\
\hline$\gamma$ & 90 & $79 \cdot 235(2)$ \\
\hline Cell volume $\left(\AA^{3}\right)$ & $963 \cdot 66(4)$ & $380 \cdot 69(9)$ \\
\hline$Z$ & 4 & 8 \\
\hline$F(000)$ & 432 & 196 \\
\hline$d_{\text {calc }}\left(\mathrm{mg} / \mathrm{m}^{3}\right)$ & 1.435 & 1.642 \\
\hline$\lambda(\AA)\left(\mathrm{Mo}-K_{\alpha}\right)$ & $0 \cdot 7103$ & $0 \cdot 7103$ \\
\hline$\mu\left(\mathrm{mm}^{-1}\right)$ & $0 \cdot 113$ & $0 \cdot 140$ \\
\hline Crystal size (mm) & $0.12 \times 0.2 \times 0.12$ & $0.14 \times 0.18 \times 0.12$ \\
\hline Diffractometer & Siemens, Smart CCD & Siemens, Smart CCD \\
\hline$T(\mathrm{~K})$ & $293(2)$ & $293(2)$ \\
\hline$\theta$ range $(\mathrm{deg})$ & $1 \cdot 89-23 \cdot 31$ & $2-24$ \\
\hline$h$ & $-10 \leq h \leq 12$ & $-4 \leq h \leq 4$ \\
\hline$k$ & $-9 \leq h \leq 13$ & $-6 \leq k \leq 10$ \\
\hline$l$ & $-8 \leq h \leq 8$ & $-11 \leq l \leq 11$ \\
\hline Total reflections & 3866 & 1596 \\
\hline Non-zero reflections & $1383[R(\mathrm{int})=0 \cdot 0365]$ & $1075[R(\mathrm{int})=0 \cdot 0719]$ \\
\hline$R[I>2 \sigma]$ & $R 1=0.0354, w R 2=0.0777$ & $R 1=0.0376, w R 2=0.0984$ \\
\hline$R$ indices (all data) & $R 1=0.0549, w R 2=0.0864$ & $R 1=0.0412, w R 2=0 \cdot 1045$ \\
\hline GOF on $F^{2}$ & $0 \cdot 048(3)$ & $1 \cdot 102$ \\
\hline $\max . e\left(\AA^{-3}\right)$ & $0 \cdot 167$ & $0 \cdot 156$ \\
\hline
\end{tabular}


graphite monochromator for the MoK $\alpha$ radiation $(40 \mathrm{kV}, 40 \mathrm{~mA})$. A hemisphere of reciprocal space was collected using SMART ${ }^{5}$ software with $2 \theta$ setting of the detector at $28^{\circ}$. The crystal-to-detector distance was $5 \mathrm{~cm}$. Data reduction was performed using the SAINT program and the orientation matrix along with the detector and cell parameters were refined for every 40 frames on all measured reflections. The crystal structures were solved by direct methods SHELXTL program ${ }^{6}$ and refined by full matrix least squares on $F^{2}$. All the non-hydrogen atoms were refined anisotropically. Hydrogen atoms were located by the difference Fourier method and were refined isotropically.

The atomic coordinates of $\mathbf{1}$ and $\mathbf{2}$ are listed in table 2. Selected bond lengths and angles for both are given in table 3. Details of the hydrogen bonds in $\mathbf{1}$ and $\mathbf{2}$ given in table 4 were computed using PLATON and the plots of arrangement of molecules were generated using XP.

\section{Results and discussion}

\subsection{Cyanuric acid-pyridine adduct, $\mathbf{1}$}

The 1:1 complex of CA with pyridine, $\mathrm{C}_{3} \mathrm{~N}_{3} \mathrm{O}_{3} \mathrm{H}_{3}: \mathrm{C}_{5} \mathrm{H}_{5} \mathrm{~N}, \mathbf{1}$, crystallizes in a monoclinic $(P 2 / c)$ space group (table 1$)$. The asymmetric unit of $\mathbf{1}$ (figure 2a) consists of one molecule each of CA and pyridine as expected. The structure of $\mathbf{1}$ shown in figure 3a reveals that the molecular tapes formed by dimeric $\mathrm{N}-\mathrm{H}$... O hydrogen bonds in $\mathrm{CA}$ are retained. The pyridine molecules replace the intertape $\mathrm{N}-\mathrm{H}$... O hydrogen bond in CA by a strong $\mathrm{N}-\mathrm{H} \ldots \mathrm{N}(\mathrm{H} \ldots \mathrm{N}, 1.75 \AA$ ) bond in addition to $\mathrm{C}-\mathrm{H} \ldots \mathrm{O}(\mathrm{H} \ldots \mathrm{O}, 2.55 \AA)$ interaction. The $\mathrm{H} . . . \mathrm{O}$ distance of $2.55 \AA$ suggests that the $\mathrm{C}-\mathrm{H} . . . \mathrm{O}$ bond is moderately strong ${ }^{7}$.

In 1, cyanuric acid is able to accommodate a foreign molecule such as pyridine without making any significant compromise in its original H-bonding features. The cell parameter along the direction of the CA tapes in both CA and $\mathbf{1}$ show a difference of only $0.05 \AA$. The increase along the $c$ axis in $\mathbf{1}$ roughly corresponds to the size of the pyridine molecule with the H-bonding distances. The structure also shows single helices of hydrogen bonded $\mathrm{CA}$ and pyridine held by the dimeric $\mathrm{N}-\mathrm{H} \ldots \mathrm{O}$ hydrogen bonds between the CA molecules (figure 4). The distance between the adjacent helices is about $5.99 \AA$. The helicity of chains here is induced by the pyridine molecules, which tilt from the plane of the CA tapes. All the CA molecules in a particular chain are in the same plane.

\subsection{Guanidinium cyanurate, 2}

Guanidinium cyanurate, $\mathbf{2}$, crystallizes in a triclinic $(P \overline{1})$ space group (table 1$)$. The asymmetric unit of $\mathbf{2}$ is shown in figure $2 \mathrm{~b}$. The asymmetric unit consists of cyanurate monoanion and the guanidinium cation. The structure of $\mathbf{2}$ contains $\mathrm{CA}$ tapes and the guanidinium cations held between the adjacent tapes by $\mathrm{N}-\mathrm{H} . . \mathrm{N}$ and $\mathrm{N}-\mathrm{H} \ldots \mathrm{O}$ hydrogen bonds as shown in figure $3 \mathrm{~b}$. The CA tapes resemble a sine-wave unlike the linear tapes present in both $\mathrm{CA}$ and $\mathbf{1}$. The axis parameter along the direction of the tapes is shorter $(10.4987 \AA)$ in comparison to that in CA (11.912 $\AA$ ) due to the sine-wave like structure of the tapes adopted by CA molecules. The effect of the negative charge on $\mathrm{N}(11)$ manifests itself in the distances of the neighbouring bonds. Thus, the $\mathrm{C}-\mathrm{N}$ bond distances of $\mathrm{C}(11)-$ $\mathrm{N}(11)$ and $\mathrm{C}(12)-\mathrm{N}(11)$ are shorter than the other $\mathrm{C}-\mathrm{N}$ distances observed in the 
fragment. The carbonyl groups adjacent to $\mathrm{N}(11)$ show an increase in the bond length. The $\mathrm{N}(12)-\mathrm{C}(12)$ and $\mathrm{N}(13)-\mathrm{C}(13)$ bonds also show an increase in their lengths. The above variations in the bond distances result from the delocalization of the negative charge on $\mathrm{N}(11)$ to the adjacent carbonyls. The increase in the bond lengths of

Table 2. Atomic coordinates and equivalent isotropic displacement parameters $\left(\AA^{2}\right)$ of 2. $U(\mathrm{eq})$ is defined as one third of the trace of the orthogonalized $U_{i j}$ tensor.

\begin{tabular}{|c|c|c|c|c|}
\hline Atom & $x$ & $y$ & $z$ & $U(\mathrm{eq})$ \\
\hline \multicolumn{5}{|l|}{1} \\
\hline $\mathrm{N}(13)$ & $0.4693(2)$ & $0 \cdot 4616(1)$ & $0 \cdot 2161(2)$ & $0.041(1)$ \\
\hline $\mathrm{N}(12)$ & $0.4632(2)$ & $0 \cdot 2698(1)$ & $0 \cdot 2315(2)$ & $0.042(1)$ \\
\hline $\mathrm{N}(11)$ & $0.6238(2)$ & $0 \cdot 3660(1)$ & $0 \cdot 3839(2)$ & $0 \cdot 041(1)$ \\
\hline $\mathrm{O}(13)$ & $0 \cdot 3132(1)$ & $0 \cdot 3653(1)$ & $0.0665(2)$ & $0 \cdot 061(1)$ \\
\hline $\mathrm{O}(12)$ & $0 \cdot 6191(1)$ & $0 \cdot 1771(1)$ & $0 \cdot 3889(2)$ & $0.051(1)$ \\
\hline $\mathrm{O}(11)$ & $0 \cdot 6220(1)$ & $0 \cdot 5547(1)$ & $0 \cdot 3798(2)$ & $0.049(1)$ \\
\hline$C(13)$ & $0.4079(2)$ & $0 \cdot 3655(2)$ & $0 \cdot 1641(3)$ & $0.041(1)$ \\
\hline $\mathrm{C}(12)$ & $0 \cdot 5719(2)$ & $0 \cdot 2656(2)$ & $0 \cdot 3370(3)$ & $0 \cdot 039(1)$ \\
\hline $\mathrm{C}(11)$ & $0 \cdot 5747(2)$ & $0 \cdot 4664(2)$ & $0 \cdot 3289(3)$ & $0.039(1)$ \\
\hline $\mathrm{N}(1)$ & $0.8477(2)$ & $0 \cdot 3703(2)$ & $0 \cdot 5823(2)$ & $0.052(1)$ \\
\hline $\mathrm{C}(1)$ & $0.9299(2)$ & $0 \cdot 2911(2)$ & $0 \cdot 5545(3)$ & $0.062(1)$ \\
\hline$C(3)$ & $1.0885(3)$ & $0 \cdot 3842(3)$ & $0.7239(4)$ & $0 \cdot 085(1)$ \\
\hline $\mathrm{C}(4)$ & $1.0054(3)$ & $0.4667(3)$ & $0 \cdot 7550(4)$ & $0.080(1)$ \\
\hline $\mathrm{C}(5)$ & $0.8861(2)$ & $0.4567(2)$ & $0 \cdot 6811(4)$ & $0 \cdot 064(1)$ \\
\hline$C(2)$ & $1.0496(2)$ & $0 \cdot 2951(3)$ & $0.6220(4)$ & $0 \cdot 080(1)$ \\
\hline $\mathrm{H}(13)$ & $0.4388(19)$ & $0 \cdot 5244(19)$ & $0 \cdot 1837(29)$ & $0.052(7)$ \\
\hline $\mathrm{H}(12)$ & $0.4319(19)$ & $0 \cdot 2066(19)$ & $0 \cdot 1998(28)$ & $0.051(6)$ \\
\hline $\mathrm{H}(5)$ & $0 \cdot 8262(23)$ & $0.5128(21)$ & $0.6967(33)$ & $0 \cdot 078(8)$ \\
\hline $\mathrm{H}(3)$ & $1 \cdot 1665(32)$ & $0 \cdot 3918(25)$ & $0 \cdot 7740(43)$ & $0 \cdot 115(11)$ \\
\hline $\mathrm{H}(1)$ & $0.9006(22)$ & $0 \cdot 2275(20)$ & $0 \cdot 4796(34)$ & $0 \cdot 074(8)$ \\
\hline $\mathrm{H}(11)$ & $0 \cdot 6998(23)$ & $0 \cdot 3664(18)$ & $0.4563(32)$ & $0 \cdot 071(7)$ \\
\hline $\mathrm{H}(4)$ & $1.0249(27)$ & $0.5255(26)$ & $0 \cdot 8289(43)$ & $0 \cdot 105(11)$ \\
\hline $\mathrm{H}(2)$ & $1 \cdot 1068(29)$ & $0 \cdot 2323(25)$ & $0 \cdot 5972(43)$ & $0 \cdot 111(10)$ \\
\hline \multicolumn{5}{|l|}{2} \\
\hline $\mathrm{N}(13)$ & $0.0635(4)$ & $0 \cdot 4576(2)$ & $0 \cdot 3216(2)$ & $0 \cdot 033(1)$ \\
\hline $\mathrm{N}(12)$ & $0 \cdot 2084(4)$ & $0 \cdot 3744(2)$ & $0 \cdot 1191(2)$ & $0.035(1)$ \\
\hline $\mathrm{O}(13)$ & $-0 \cdot 1664(4)$ & $0 \cdot 5816(1)$ & $0 \cdot 1524(1)$ & $0.044(1)$ \\
\hline $\mathrm{N}(11)$ & $0.4450(4)$ & $0 \cdot 2394(2)$ & $0 \cdot 2904(1)$ & $0.037(1)$ \\
\hline $\mathrm{O}(12)$ & $0 \cdot 2826(4)$ & $0 \cdot 3326(2)$ & $0.4883(1)$ & $0.049(1)$ \\
\hline $\mathrm{N}(3)$ & $1 \cdot 2808(5)$ & $-0 \cdot 2266(2)$ & $0 \cdot 3070(2)$ & $0 \cdot 040(1)$ \\
\hline $\mathrm{O}(11)$ & $0 \cdot 5778(4)$ & $0 \cdot 1695(2)$ & $0 \cdot 0836(1)$ & $0 \cdot 050(1)$ \\
\hline $\mathrm{N}(2)$ & $0 \cdot 8662(5)$ & $-0.0340(2)$ & $0 \cdot 3704(2)$ & $0 \cdot 042(1)$ \\
\hline $\mathrm{C}(13)$ & $0.0225(5)$ & $0.4780(2)$ & $0 \cdot 1951(2)$ & $0 \cdot 031(1)$ \\
\hline $\mathrm{N}(1)$ & $1.0551(6)$ & $-0.0696(2)$ & $0 \cdot 1582(2)$ & $0 \cdot 053(1)$ \\
\hline $\mathrm{C}(12)$ & $0 \cdot 4181(5)$ & $0.2556(2)$ & $0 \cdot 1642(2)$ & $0.033(1)$ \\
\hline $\mathrm{C}(1)$ & $1.0687(5)$ & $-0 \cdot 1105(2)$ & $0 \cdot 2773(2)$ & $0 \cdot 032(1)$ \\
\hline $\mathrm{H}(13)$ & $-0 \cdot 0394(68)$ & $0 \cdot 5200(27)$ & $0 \cdot 3744(26)$ & $0 \cdot 049(6)$ \\
\hline $\mathrm{H}(12)$ & $0 \cdot 1969(53)$ & $0 \cdot 3794(20)$ & $0 \cdot 0414(25)$ & $0.032(6)$ \\
\hline $\mathrm{H}(3 \mathrm{~A})$ & $1.4238(66)$ & $-0 \cdot 2704(25)$ & $0 \cdot 2487(25)$ & $0 \cdot 044(6)$ \\
\hline $\mathrm{H}(3)$ & $1 \cdot 3155(67)$ & $-0 \cdot 2469(26)$ & $0 \cdot 3886(28)$ & $0 \cdot 055(7)$ \\
\hline $\mathrm{H}(2 \mathrm{~A})$ & $0.7439(68)$ & $0 \cdot 0499(30)$ & $0 \cdot 3511(24)$ & $0.051(7)$ \\
\hline $\mathrm{H}(1)$ & $1 \cdot 1976(73)$ & $-0 \cdot 1179(28)$ & $0.091(28)$ & $0 \cdot 066(8)$ \\
\hline $\mathrm{H}(2)$ & $0 \cdot 8639(89)$ & $-0.0693(34)$ & $0.4399(34)$ & $0.084(11)$ \\
\hline
\end{tabular}


Table 3. Bond lengths and angles in $\mathbf{1}$ and $\mathbf{2}$.

Bond lengths, 1

$1 \cdot 367(2)$
$0 \cdot 85(2)$
$1 \cdot 371(2)$
$1 \cdot 363(2)$
$0 \cdot 95(2)$
$1 \cdot 211(2)$
$1 \cdot 320(3)$
$1 \cdot 355(4)$
$1 \cdot 359(4)$
$0 \cdot 90(3)$
$0 \cdot 91(3)$
$1 \cdot 00(3)$

$\mathrm{C}(2)-\mathrm{H}(2)$

Bond angles, 1

\section{$125 \cdot 0(2)$ \\ $120(2)$ \\ $125 \cdot 1(2)$ \\ $123 \cdot 9(2)$ \\ $117 \cdot 8(14)$ \\ $123 \cdot 0(2)$ \\ $121 \cdot 9(2)$ \\ $115 \cdot 8(2)$ \\ $115 \cdot 8(2)$ \\ $123 \cdot 3(3)$ \\ $119 \cdot 8(14)$ \\ $124(2)$ \\ $118 \cdot 7(3)$ \\ 119(2) \\ $116(2)$ \\ 119(2)}

$1 \cdot 358(2)$
$1 \cdot 389(2)$
$0 \cdot 850(3)$
$1 \cdot 353(2)$
$1 \cdot 387(2)$
$0 \cdot 820(3)$
$1 \cdot 233(2)$
$1 \cdot 342(2)$
$1 \cdot 345(2)$
$1 \cdot 242(2)$

$\mathrm{N}(3)-\mathrm{C}(1)$

$\mathrm{N}(3)-\mathrm{H}(3 \mathrm{~A})$

$\mathrm{N}(3)-\mathrm{H}(3)$

$\mathrm{O}(11)-\mathrm{C}(11)$

$\mathrm{N}(2)-\mathrm{C}(1)$

$\mathrm{N}(2)-\mathrm{H}(2 \mathrm{~A})$

$\mathrm{N}(2)-\mathrm{H}(2)$

$\mathrm{N}(1)-\mathrm{C}(1)$

$\mathrm{N}(1)-\mathrm{H}(1 \mathrm{~A})$

$\mathrm{N}(1)-\mathrm{H}(1)$

$\mathrm{O}(13)-\mathrm{C}(13)-\mathrm{N}(13)$

$\mathrm{N}(12)-\mathrm{C}(13)-\mathrm{N}(13)$

C(1)-N(1)-H(1A)

C(1)-N(1)-H(1)

$\mathrm{H}(1 \mathrm{~A})-\mathrm{N}(1)-\mathrm{H}(1)$

$\mathrm{O}(12)-\mathrm{C}(12)-\mathrm{N}(11)$

$\mathrm{O}(12)-\mathrm{C}(12)-\mathrm{N}(13)$

$\mathrm{N}(11)-\mathrm{C}(12)-\mathrm{N}(13)$

$\mathrm{O}(11)-\mathrm{C}(11)-\mathrm{N}(11)$

$\mathrm{O}(11)-\mathrm{C}(11)-\mathrm{N}(12)$

$\mathrm{N}(11)-\mathrm{C}(11)-\mathrm{N}(12)$

$\mathrm{N}(1)-\mathrm{C}(1)-\mathrm{N}(3)$

$\mathrm{N}(1)-\mathrm{C}(1)-\mathrm{N}(2)$

$\mathrm{N}(3)-\mathrm{C}(1)-\mathrm{N}(2)$
$1 \cdot 370(2)$

$1 \cdot 365(2)$

$0 \cdot 86(2)$

$1 \cdot 365(2)$

$1.228(2)$

$1 \cdot 223(2)$

$1 \cdot 327(3)$

$1 \cdot 359(4)$

$1 \cdot 368(5)$

$1.369(4)$

$0 \cdot 95(3)$

$115(2)$

$115 \cdot 6(14)$

$119 \cdot 1(14)$

$118 \cdot 2(14)$

$122 \cdot 7(14)$

$114 \cdot 3(2)$

$122 \cdot 2(2)$

$122 \cdot 5(2)$

$117 \cdot 5(2)$

$116.9(14)$

118.9(3)

118(2)

122(2)

116(2)

118.9(3)

122(2)

$1 \cdot 318(3)$

$0 \cdot 840(3)$

$0 \cdot 890(3)$

$1 \cdot 240(2)$

$1 \cdot 336(3)$

$0 \cdot 890(3)$

$0 \cdot 800(4)$

$1 \cdot 303(3)$

$0.840(3)$

$0 \cdot 870(3)$

$123 \cdot 4(2)$

$114 \cdot 1(2)$

118(2)

119(2)

123(3)

$122 \cdot 8(2)$

$117 \cdot 6(2)$

$119 \cdot 7(2)$

$123 \cdot 1(2)$

$117 \cdot 3(2)$

$119.6(2)$

$121 \cdot 0(2)$

$119.4(2)$

$119 \cdot 6(2)$ 
Table 4. Hydrogen bond distances $(\AA)$ and angles $\left({ }^{\circ}\right)$ in $\mathbf{1}$ and $\mathbf{2}^{\mathrm{a}}$.

\begin{tabular}{llllllc}
\hline D & H & A & D-H & H...A & D...A & D-H...A \\
\hline $\mathbf{1}$ & & & & & & \\
N(11) & H(11) & N(1) & $0 \cdot 966$ & $1 \cdot 776$ & $2 \cdot 738$ & 174 \\
N(12) & H(12) & O(11) & $0 \cdot 878$ & 1.967 & $2 \cdot 839$ & 171 \\
N(13) & H(13) & O(12) & $0 \cdot 843$ & $2 \cdot 004$ & $2 \cdot 846$ & 175 \\
C(2) & H(2) & O(13) & $0 \cdot 995$ & $2 \cdot 551$ & $3 \cdot 486$ & 156 \\
$\mathbf{2}$ & & & & & & \\
N1 & H1 & O11 & $0 \cdot 871$ & $2 \cdot 035$ & $2 \cdot 859$ & 157 \\
N1 & H1A & O11 & $0 \cdot 844$ & 1.993 & $2 \cdot 831$ & 172 \\
N2 & H2A & N11 & $0 \cdot 891$ & $2 \cdot 111$ & $2 \cdot 999$ & 174 \\
N3 & H3 & O12 & $0 \cdot 891$ & $2 \cdot 142$ & $2 \cdot 908$ & 143 \\
N3 & H3A & O13 & $0 \cdot 840$ & $2 \cdot 106$ & 2.916 & 161 \\
N12 & H12 & O13 & $0 \cdot 820$ & $2 \cdot 070$ & $2 \cdot 886$ & 172 \\
N13 & H13 & O12 & $0 \cdot 848$ & $2 \cdot 091$ & $2 \cdot 939$ & 177 \\
\hline
\end{tabular}

${ }^{\mathrm{a}} \mathrm{D}$ - donor; $\mathrm{H}$ - acceptor

(a)
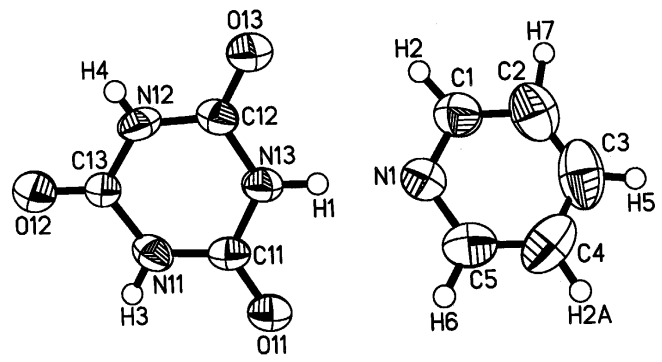

(b)
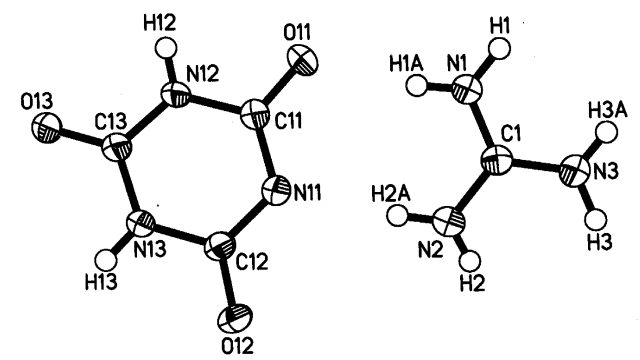

Figure 2. ORTEP plots of $\mathbf{1}$ (a) and $\mathbf{2}$ (b) showing 50\% thermal ellipsoids.

the above mentioned $\mathrm{C}-\mathrm{N}$ distances can be attributed to the suppression of the resonance effect involving $\mathrm{N}(12)$ and $\mathrm{N}(13)$ lone pairs due to the dominating influence of the negatively charged participant. The greater availability of the lone pairs on $\mathrm{N}(12)$ and $\mathrm{N}(13)$ towards resonance involving the third carbonyl reflect in the decrease in bond lengths of the $\mathrm{N}(12)-\mathrm{C}(13)$ and $\mathrm{N}(13)-\mathrm{C}(13)$ bonds and increase in the $\mathrm{C}(13)-\mathrm{O}(13)$ bond length. It is to be noted that these changes in bond lengths are of lower magnitude when compared to that involving the $\mathrm{N}(11)$ anion. There is about $16.4 \%$ increase in the 
(a)

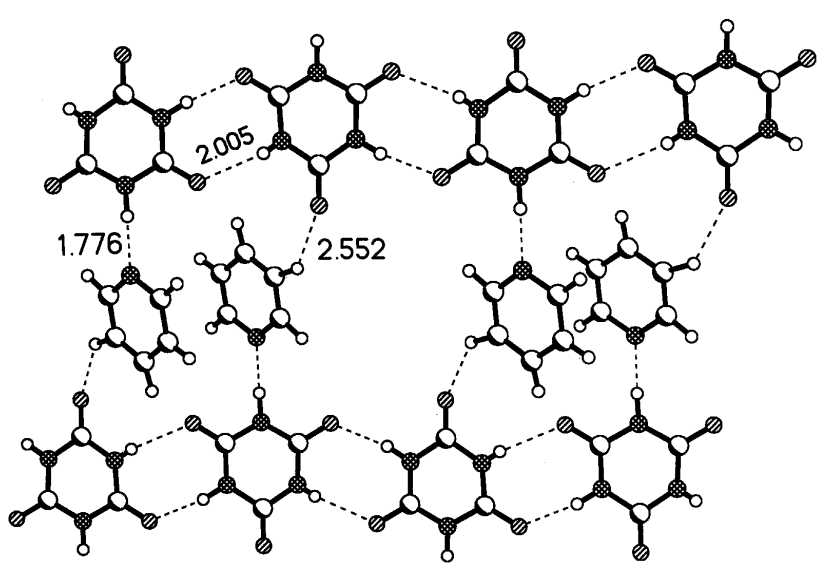

(b)

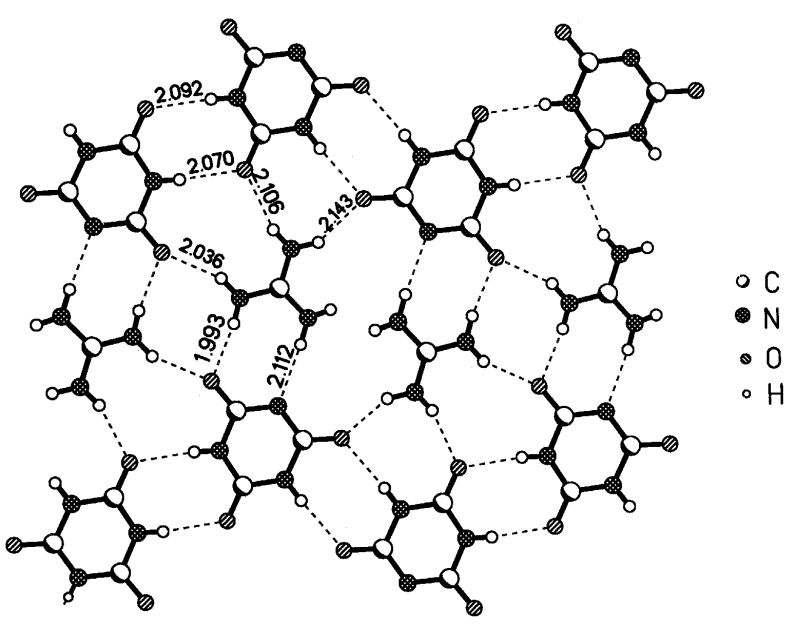

Figure 3. (a) Structure of the 1:1 CA-pyridine adduct showing the CA tapes along the $b$ axis and $\mathrm{N}-\mathrm{H}$... N and $\mathrm{C}-\mathrm{H}$... O hydrogen bonds between $\mathrm{CA}$ and pyridine molecules. (b) Structure of guanidinium cyanurate showing the wave-like pattern adopted by $\mathrm{CA}$ tapes and the guanidinium cations holding the tapes by $\mathrm{N}-\mathrm{H}$... O and $\mathrm{N}-\mathrm{H}$.... $\mathrm{N}$ hydrogen bonds.

double bond character of the $\mathrm{C}(11)-\mathrm{N}(11)$ and $\mathrm{C}(12)-\mathrm{N}(11)$ bonds and about $7 \cdot 5 \%$ of the $\mathrm{C}(13)-\mathrm{N}(12)$ and $\mathrm{C}(12)-\mathrm{N}(13)$ bonds. Four of the six hydrogens in the guanidinium fragment participate in $\mathrm{N}-\mathrm{H}$... O hydrogen bonding with the carbonyl oxygens of CA with distances of $2.036 \AA, 2 \cdot 106 \AA, 2.143 \AA$, and $1.993 \AA$. The last is a particularly strong hydrogen bond, considering that the $\mathrm{N}-\mathrm{H} \ldots \mathrm{N}$ bond angle is $172^{\circ}$. Of the two remaining hydrogens, $\mathrm{H}(2)$ bonds to anionic $\mathrm{N}(11)$ and the other remains free. The bonding distance of $\mathrm{N}(2)-\mathrm{H}(2) \ldots \mathrm{N}(11)(\mathrm{H} \ldots \mathrm{N}, 2 \cdot 11 \AA)$ is comparable with the other $\mathrm{N}-\mathrm{H}$... O distances in the structure. The hydrogen, $\mathrm{H}(2 \mathrm{~A})$ of the guanidinium ion, which does not participate in hydrogen bonding, has the shortest $\mathrm{N}-\mathrm{H}$ distance of all the $\mathrm{N}-\mathrm{H}$ bonds. 

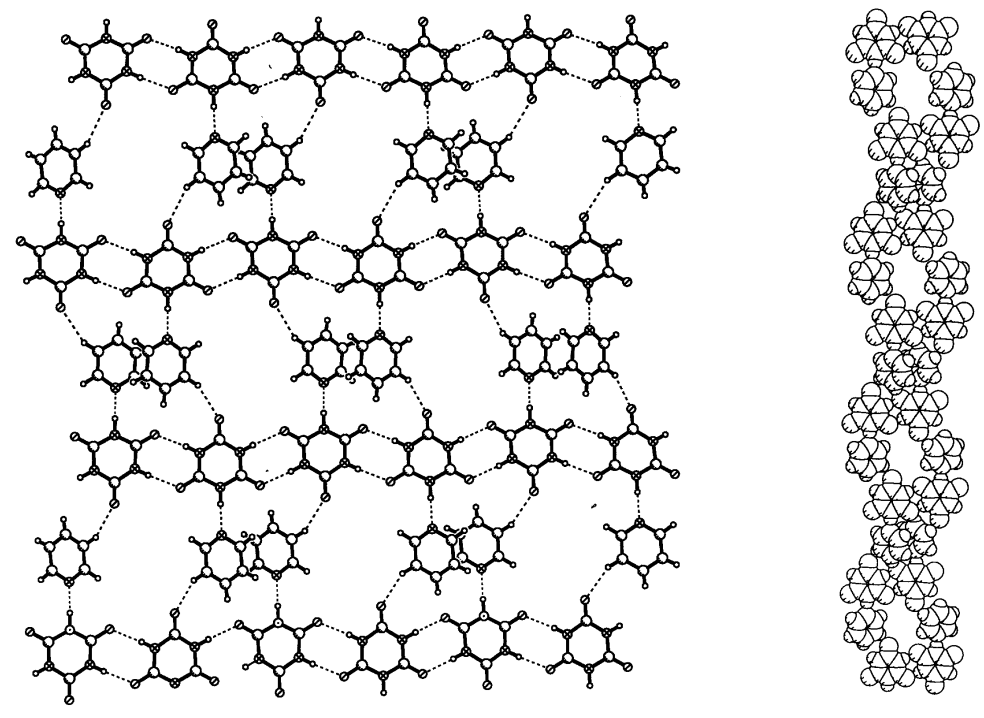

Figure 4. Helical hydrogen-bonded chains of $\mathrm{CA}$ and pyridine molecules held by dimeric $\mathrm{N}-\mathrm{H}$... O hydrogen bonds between the $\mathrm{CA}$ molecules.

\section{Conclusions}

Crystal structures of the 1:1 cyanuric acid-pyridine complex, $\mathbf{1}$, and guanidinium cyanurate, 2, illustrate how cyanuric acid accommodates the pyridine and the guanidinium cations without compromising the dimeric hydrogen-bonded tape present in its parent structure. The only difference is that in $\mathbf{2}$ the CA tapes are curved, unlike the linear tapes in the original structure of $\mathrm{CA}$ and in $\mathbf{1}$. In 1, the $\mathrm{N}-\mathrm{H} \ldots \mathrm{N}$ hydrogen bonds formed by the pyridine molecules take the role of the single intermolecular $\mathrm{N}-\mathrm{H}$...O bond in CA, holding the tapes together. A novel feature in $\mathbf{1}$ is the formation of a beautiful helical structure of the hydrogen bonded CA-pyridine chains.

\section{Acknowledgements}

The author thanks Prof C N R Rao for suggesting the problem and for his guidance. The author would also like to thank Dr G U Kulkarni for helpful discussion.

\section{References}

1. Coppens P and Vos A 1971 Acta Crystallogr. B27 146

2. Ranganathan A, Pedireddi V R, Sanjayan G, Ganesh K N and Rao C N R 2000 J. Mol. Struct. 52287

3. Shieh H S and Voet D 1976 Acta Crystallogr. B32 2354

4. Ranganathan A, Pedireddi V R and Rao C N R 1999 J. Am. Chem. Soc. 1211752

5. Siemens Analytical X-ray Instruments Inc. 1995 Madison, WI

6. SHELXTL (SGI version) Siemens Analytical X-ray Instruments Inc. 1995 Madison, WI

7. Desiraju G R 1991 Acc. Chem. Res. 24290 